\title{
Jaime Rodríguez-Arana Muñoz (ed) Recognition of Foreign Administrative Acts. Springer International Publishing Switzerland 2016. Ius Comparatum - Global Studies in Comparative Law 10. 388 pages
}

\author{
BY JÁNOS FAZEKAS*
}

The recognition of administrative acts is a very controversial topic of administrative law as it is in the classical sphere of administrative proceedings law and therefore a traditional subject regarding national sovereignty. These acts refer to a national territory and to national citizens, who live mainly at their home countries but sometimes live or stay abroad. In these acts, the national administrative authorities adopt individual acts, in which they license, oblige or sanction persons which are under the jurisdiction of national public administration. Administrative law tends to exclude the influence of foreign administrative law regimes and tries to defend its own force.

On the other hand, the globalization of administrative law is a phenomenon which can not longer be held back. Within the European Union and all over the world, the free movement of persons, goods, capital and services as well has weakened borders. Consequently, national administrative law had to become more flexible and open to new developments, eg. recognition end execution of foreign administrative acts. In addition, national administrative legal systems faced transnational challenges. The regulatory authorities of the European Union and international organizations have adopted normative and individual administrative acts regarding the citizens and organizations of the member states as well, which must be recognized or executed by member states.

Modern administrative law regimes must comply at once with these new challenges. Under these circumstances, it has some additional scholar value to examine the general theoretical characteristics of the topic and to have a more detailed outlook to the national level of the regulation. A successful research of the topic may allow a very strong basis for further developments of the national legislations and for new ways of thinking in jurisprudence.

The book begins with a general report on foreign administrative acts (authors: Jaime Rodríguez-Arana Muñoz, Marta García Pérez, Juan José Pernas García and Carlos Aymerich Cano), which lays down the general theoretical foundations of the analysis of the recognition of foreign administrative acts. The paper initially examines the notion of an administrative act and its classification as 'foreign' in the analyzed countries. After general considerations on the usual administrative procedure for adopting an administrative act, it scans the service of administrative acts, especially in other countries (not in the ones where the act has been adopted). The study then analyzes the topics of recognition and execution and the relevant

* Assistant professor, Eötvös Loránd University, School of Law, Budapest. E-mail: fazekas. janos@ajk.elte.hu 
international conventions. In the end, the paper covers the doctrinal treatment of the subject of foreign administrative acts by scholars in the analyzed countries. In summary, the general report states that the subject has been poorly treated in the analyzed countries and it would be necessary to deepen the study in order to measure the possible effects of the conception on different legal cultures, procedural rights and judicial guarantees of the recipients of such acts.

Juan José Pernas García's paper (The European Union's Role in the Progress Towards the Recognition and Execution of Foreign Administrative Acts: The Principle of Mutual Recognition and the Transnational Nature of Certain Administrative Acts) examines a subject which affects several sectors. The aforementioned study declares that the EU has supported the mutual recognition of national administrative acts and promoted providing extraterritorial effectiveness to the administrative decisions of the Member States. The EU carried out this aim through secondary legal norms, in sectors where the EU has intense competence or powers eg. the marketing of food ingredients or use and marketing of biocides. These secondary norms express the principle of mutual recognition, which has been the axis around which the EU internal market has been built.

Another study, Giacinto della Cananea's 'From the Recognition of Foreign Acts to Trans-national Administrative Procedures' deals with a theoretical notion of recognition and its two distinct models. The paper suggests that a third - the transnational - model has emerged.

The further studies, written by national rapporteurs, investigated the subject from a national-territorial viewpoint. The national reports unfold the state and conditions of selected countries' regulation on recognition and execution of administrative acts.

The paper of Libardo Rodríguez-Rodríguez and Jorge Enrique Santos-Rodríguez ('The Incorporation of the Acts of the Andean Community of Nations into Internal Legal Systems') examines the impact of Andean communitarian law over the national administrative regulation of the Member States of the Andean Community of Nations (The Andean Community is a customs union including Bolivia, Colombia, Ecuador and Peru). The study states that the primary and secondary norms of Andean communitarian law can be adopted to the Member States within the framework of legal dualism. Nevertheless, the primacy of communitarian law does not preclude the application of the principle of hierarchy in the incorporation of Andean law to domestic law because sometimes it is necessary to determine the degree to which incorporation of communitarian rules takes place in domestic legal systems.

The paper on Australia by Justice John Griffiths ('Recognition of Foreign Administrative Acts') describes the main theme (enforcement of other states' administrative acts) from the viewpoints within the federation of Australia and Australia's recognition and enforcement arrangements with different countries.

Romeu Felipe Bacellar Bacellar Filho and Tatyana Scheila Friedrich's study ('Foreign Administrative Acts in Brazil') examines the problem that Brazil has no regulation on foreign administrative acts which makes recognition and enforcement of these decisions rather complicated. Brazil has not also ratified the Apostille Convention. The rules on recognition and enforcement of foreign acts are drawn from various sources, e. g. through analogy with the general rules of private international law and international cooperation. There is also no doctrinal approach to this subject in the country. The paper states that this situation must be urgently changed if Brazil intends to intensively participate in international scenarios. 
Vallo Olle and Triinu Rauk's paper on Estonia (Foreign Administrative Acts: The Case of Estonia) deals with the contradiction that here have been several practical steps in Estonia regarding recognition of foreign administrative acts but the subject has not been examined often by legal scholars. The study concludes stating that in order to reach further development more steps in both ways are needed.

M. Timothée Paris' study ('La reconnaissance des actes administratifs étrangers au droit français') looks at the recognition of foreign administrative acts in France. The paper states that in French law administrative acts issued by foreign states and international organizations can be qualified as foreign acts. However, European secondary law acts must be considered like European administrative acts. The study examines the consequences of this distinction.

The paper on Germany (Ulrich Stelkens and Michael Mirschberger: The Recognition of Foreign Administrative Acts: A German Perspective) describes the very complex system of transborder administrative action. The 'carapace of sovereignty' is only opened by EU law or by bilateral or multilateral international treaties on the basis of mutual trust.

The study 'On the Recognition of Foreign Administrative Acts in Greece' by Alexandra E. Douga starts from non-existence of the framework for the recognition and enforcement of foreign administrative acts in Greece. The paper suggests national legislation on the basis of theoretical and practical experiences. The author's opinion is that common recognition and enforcement criteria and procedures should be adopted at European level.

The country report on Hungary (István Balázs, Marianna Nagy and Krisztina Rozsnyai: La reconnaissance des actes administratifs étrangers en Hongrie) states that there are several functioning mechanisms for the acceptance and execution of foreign administrative acts in Hungary even though the country has not signed the European Convention in International Service. Therefore an EU-regulation on foreign notification would help to solve the problem of slow procedure of assistance.

The paper on Poland (Zbigniew Kmiecieak, Przemyslaw Florjanowicz-Blachut and Robert Siucinski: Notion and Recognition of Foreign Administrative Acts in Poland) underlines the problem that the subject of enforcement of foreign administrative acts has not been theoretically examined in Poland. However, the increasing importance of the topic should lead to new approaches, especially under the competence of the EU.

The paper titled 'Recognition of Foreign Administrative Acts in Portugal' by Dulce Lopes emphasizes that the subject has attracted great interest from Portuguese scholars and is under rethinking. Despite of this renewal, legal regulation needs some modernization, because it is still rather fragmented and recognition demands are coming from international and EU law.

The country report on Spain (Carlos Aymerich Cano: Searching for Foreign Administrative Acts in Spanish Law) highlights that there is no explicit regulation on the validity, efficacy and enforceability of foreign administrative acts in Spanish administrative procedural law. Therefore the international and EU law provides framework for handling the problems regarding these acts. In addition, private international law could serve as a guide for further development.

Henrik Wenander's paper 'The Recognition of Foreign Administrative Decisions in Sweden' states that there are no general rules on the procedures of recognition of foreign administrative acts. The subject is under the scope of the general administrative procedure principles, rules and special legislation of international and EU law also deal with these matters. Special feature of the Swedish development is the importance of the international agreements within the framework of the Nordic cooperation. 
Myriam Senn's study 'The Recognition of Foreign Administrative Acts in Switzerland' emphasizes that the treatment of foreign administrative acts is not unified in Switzerland it depends on the area concerned and blocking statutes may apply. Several efforts has been made in order to change this regulatory situation, although the theoretical works on that matter are nor very elaborated.

The country report on Turkey (Çağla Tansuğ: Les actes administratifs étrangers et le droit turc) is based on the statement that the notion 'foreign administrative act' is not very elaborated in Turkish administrative law. However, administrative legal theory does not give detailed definitions and therefore the national and international legal framework must handle the gap between foreign administrative acts and Turkish administrative law.

John C. Reitz's paper 'Recognition of Foreign Administrative Acts in the United States' describes the complex situation of foreign administrative acts in US administrative law. These acts can be under the authority of mutual recognition agreements (MRA's) or similar treaties. The regulations give a clear legal basis for recognition, based on common law. In addition, common law is subject to exceptions to protect crucial policies of the United States.

The national reports follow the same structure as the general report. The main difference between them is the scope and handling of the sources. Some chapters uses mainly (or only) legal statutes as sources, some others cover scholar sources, too (monographs, articles etc.). It makes the profile of the book a bit uneven with some chapters rather descriptive, while others try to set up a better established theoretical background. It would have been better if the editors were more rigorous with the authors and made them follow the second path.

Furthermore, it would have been very helpful for a complete index of concepts and terms, names and a comprehensive bibliography to be attached to the book. In the current form, the book has no index and references are only attached to each chapter, which is very useful from the viewpoint of the analyzed countries. However, this does not allow a general outlook to the scientific background of the whole topic of the book. A detailed index of concepts and names would enhance and simplify the work of the interested researchers. In addition, in the field of administrative procedural law it is highly recommended to compile an (at least selected) index of court and constitutional court cases relevant regarding the examined topic.

Nevertheless, the book has outstanding value because of the rarity of scientific works on the analyzed topic and the above mentioned challenges (globalization of administrative law on the one hand and the significant role of national administrations on the other hand), which modern national public administrations must nowadays face. Between this very controversial theoretical and practical framework, jurisprudence and legal practitioners must find new ways of thinking in order to help national and international legislation and adjudication to find solutions for complicated cases regarding foreign administrative acts. The book can be a rather effective contribution to this very complex work. 